\title{
Elektronlokalizáció és a kémiai kötés
}

\author{
SURJÁN Péter \\ ELTE Eötvös Loránd Tudományegyetem, Kémiai Intézet, Elméleti Kémiai Laboratórium, \\ Pázmány Péter sétány 1/A, 1117 Budapest
}

\section{Bevezetés: akiktől tanultam}

A hazai kvantumkémiai kutatások igen korán, már a második világháború előtt elkezdődtek. Fényes Imre, Gombás Pál Kolozsvárt majd Budapesten, később Szépfalusy Péter és Gáspár Rezső az atomok statisztikus és a pszeudopotenciálok elméletében kezdtek dolgozni és alkottak nemzetközi szinten figyelemre méltó eredményeket. Török Ferenc kísérleti spektroszkópusként kezdett kvantumkémiával foglalkozni, kiterjesztve ezzel a korábban nálunk csak fizikusok által múvelt kvantumkémiát a kémikus társadalomra. Kapuy Ede volt az első, aki a címben említett elekronlokalizáció valamint a később említendő geminál-elmélet müvelését kezdte Magyarországon, munkásságával nemzetközi visszhangot keltve. Ladik János elsősorban a polimerek kvantumkémiájának müvelésével és biológiai rendszerekre végzett számításokkal került a nemzetközi élvonalba. Kajtár Mártont sem kell ebben a folyóiratban bemutatni: a kvantumkémia szempontjából az Ö jelentősége abban áll, hogy kémikusként felfedezte a kvantummechanika alkalmazásának gyakorlati jelentőségét, megértette a kvantumkémia tudományának alapjait, munkájában alkalmazta, elméleti beállítottságú kutatókkal együtmüködött, és mindezt professzionálisan tanította. Nem csoda, hogy fiatal kutatóként csodálattal és tisztelettel tekintettem ezekre a példaképekre, akiket (Gombás Pál kivételével) volt még szerencsém személyesen megismerni (Kajtár Mártonnal és Ladik Jánossal közös publikációink is voltak), de sajnos ma már nincsenek közöttünk.

A jelenleg is aktív tudósok közül öt nevet emelnék ki, akikkel szoros kapcsolatban voltam és vagyok: Pulay Péter, Kertész Miklós, Náray Szabó Gábor, Mayer István és Kürti Jenő nevét. Pulay a legismertebb magyar kvantumkémikus, büszke vagyok, hogy sokat diszkutálhattam vele komplikált kvantumkémiai problémákról. Kertész Miklós témavezetőm volt, amidőn a fizikus diplomához szükséges szaklaboratóriumi munkát végeztem az MTA KKKI-ban. A diploma után Náray-Szabó Gábor mellett kezdtem dolgozni, és ő vezetett be az elektronlokalizáció elméletébe, legfóképpen megértette velem ennek fontosságát. Ebben a munkában vett részt Mayer István is, akivel több évtizedes gyümölcsöző együttmüködésünk kezdődött. Minden bizonnyal Tőle tanultam a legtöbbet, túlzás nélkül tekinthetem Öt mesteremnek. $\mathrm{Az}$ is nagy élmény volt, amikor bizonyos dolgokat együtt tanultunk meg vele. Kürti Jenő évfolyamtársam volt, és kísérleti fizikusként kezdett dolgozni. Érdeklődése később fordult a kvantumkémia szilárdtest-fizikai alkalmazásai felé, és ezen a területet sok sikeres együttmüködésünk volt.
Külön említeném meg Ángyán János barátomat, aki alig volt fiatalabb nálam, pályatársam volt és évtizedekig dolgoztunk együtt. Sajnos nemrégen őt is elveszítettük.

Nem sorolom fel munkatársaim között tanítványaimat, pedig igazán sokat tanultam tölük is. Többen közülük vezető oktatók, és komoly nemzetközi elismertségre tettek szert.

\section{Mi a kvantumkémia?}

A kvantumkémia kapcsán tudományági besorolás szempontjából két kérdést szoktak feltenni: vajon a fizikához vagy a kémiához tartozik-e, és (ami ettől kicsit különböző kérdés) kik müvelik elsősorban, fizikusok vagy kémikusok?

Az utóbbi kérdésre könnyebb válaszolni: ez egyszerüen országonként és időszakonként változó. A skandináv államokban elsősorban fizikusok foglalkoznak kvantumkémiával, Észak Amerikában csaknem kizárólag kémikusok. Magyarországon a fizikus irányból indult a fejlődés, ma mindkettő megtalálható.

Hogy hova tartozik ez a diszciplína, már bonyolultabb kérdés. Nyilvánvaló, hogy ennek a tudománynak az alapjai a kvantummechanikában, tehát a fizikában vannak, de az is igaz, hogy leggyakoribb célja kémiai kérdések megválaszolása. Anyagtudományi alkalmazások esetén megint közelebb kerülhet pl. a szilárdtest fizikához. Lehetne határterületnek, vagy divatos szóval "interdiszciplináris" tudománynak mondani - ebben az értelemben mindkettőhöz tartozik. Az ellenkező véleményt jól kifejezi egy tudománytörténeti könyv ${ }^{1}$ "Neither Physics nor Chemistry: a History of Quantum Chemistry" címe.

Jómagam kutatásaim során azt a hozzáállást választottam, hogy fizikus szemlélettel keresem a módszerfejlesztések lehetőségét és a kémiai jelenségek értelmezését illetve a kémiai kérdésekre adható válaszokat.

\section{Kutatási területek}

Kvantumkémiával diplomázó koromtól, 1978-tól foglalkozom, és érdeklődésem elsősorban az alábbi területekre terjed ki:

- CD spektroszkópia

- anyagtudomány

- az elektronkorreláció elmélete

- lokalizált elektronok

- perturbációszámítás és kémiai alkalmazásai 
Az alábbiakban ezekhez a tématerületekhez szeretnék néhány gondolatot füzni a legfontosabb konkrét eredmények említésével.

\subsection{CD spektroszkópia}

A cirkuláris dikroizmus spektroszkópiában az optikai rotátorerősség számításának elméletével foglalkoztam. Az itt kifejlesztett módszerek alkalmazásai során nagy örömmel dolgoztam együtt - többek között - Kajtár Mártonnal, Hermecz Istvánnal és Hollósi Miklóssal. A témába Kajtár kérésére Kertész Miklós vezetett be még hallgató koromban.

\subsection{Anyagtudomány}

Ezen a területen a vezető polimerek, fullerének, nanocsövek voltak vizsgálataink tárgyai.

A polimerek kapcsán két fontos eredményröl tennék említést: Kertész Miklóssal mi írtuk le először a szolitonok csapdázódását poliacetilénben. Kürti Jenővel pedig kidolgozunk egy elméleti módszert olyan új anyagok tervezésére, amelyek minél kisebb tiltott sávszélességgel rendelkeznek. Az általunk javasolt egyik vegyület egy közeli analógját később előállították ${ }^{2}$, és a mérések visszaigazolták az elméleti eredményeket.

A fullerének szerkezetének kutatásában a legfontosabb eredmény a C60 molekula triplett állapotának zérustér felhasadásának értelmezése volt. Ez a relativisztikus eredetü jelenség ebben az esetben a spin-spin kölcsönhatás következménye, és csak azért nem zérus, mert a triplett állapotba történő gerjesztés során az ikozaéderes molekula Jahn-Teller torzulást szenved. A kísérleti kollégák nem értettek egyet abban, hogy a torzult állapot szimmetriája $\mathrm{D}_{5 \mathrm{~d}}$ vagy $\mathrm{D}_{2 \mathrm{~h}}$. Kimutattuk, hogy az előbbi valósul meg oldatban, míg kristályos anyag esetén az utóbbi.

A nanocsövek vonatkozásában is megvizsgáltuk a Jahn-Teller torzulások lehetőségét és a zérustér felhasadásokat. A torzulások mértéke ezen rendszerek esetében nagyságrendekkel nagyobbnak adódott, mint a merevebb szerkezetű klozo-klasztereknél. Speciális modellt dolgoztunk ki a különböző átmérőjü nanocsövek "intercső" kölcsönhatásainak leírására.

\subsection{Az elektron korreláció elmélete}

Ebben a pontban csak címszavakban sorolok fel néhány eredményt: "Connected" momentumok alkalmazása, geminál-alapú multi-referencia konfigurációs kölcsönhatás eljárás kifejlesztése, gerjesztett állapotokat leíró egyenletek ortogonalitási kényszerek alkalmazásával, magas gerjesztések alkalmazása csatolt klaszter módszerekkel, multi referenciás csatolt klaszter elmélet (Kállay Mihállyal), magas rangú Hartree-Fock módszerek tárgyalása, csatolt klaszter elmélet általánosítása a momentumok módszerének alkalmazásával, a csatolt klaszter egyenletek stabilitási feltételeinek megadása, összetett részecskék elmélete. Ezen eredmények többsége diákjaimmal együttmüködésben született.

\subsection{Elektronlokalizáció és a kémiai kötés modellje}

A molekulapályák térbeli lokalizálhatósága régóta ismert tény. Náray-Szabó Gáborral, Mayer Istvánnal, később Ángyán Jánossal és Ferenczy Györggyel müveltük ezt a területet. Célunk kezdetben az volt, hogy a kizárólag analízis céljára bevezetett a posteriori, azaz utólagos pályalokalizációs eljárások helyett a priori lokalizált pályázat építsünk fel, számottevően meggyorsítva ezzel molekuláris hullámfüggvények konstruálását. Érdekes módon ezekből a metodikai tanulmányokból egy kémia szempontból jelentős elvi eredmény is született. Az derült ki ugyanis, hogy a klasszikus, kétcentrumos kötéseknek megfelelő két atomra szigorúan lokalizált molekulapályák nem adnak elég pontos leírást, muszáj figyelembe vegyük a kémiai kötések között fellépő delokalizációs effektusokat. Ezeknek a delokalizációs korrekcióknak két fajtáját sikerült azonosítani: a téren és a kötéseken át (through space és through bond) terjedö kölcsönhatásokat. Ez a distinkció szép magyarázattal szolgált a forgási barrierek eredével kapcsolatban. Igazoltuk, hogy a téren át terjedő kölcsönhatások már a perturbációszámítás 1. rendjében megjelennek, az egy kötésen keresztül terjedők a második rendben, az $\mathrm{N}$ kötésen terjedők pedig csak az $\mathrm{N}+1$-edik rendben jelennek meg. Ezért a magasabb rendü effektusoknak igen kicsi szerepe van a forgási barrierek értelmezésében, a domináns kölcsönhatás a vicinális kötések között téren át terjed.

A lokalizált molekulapályák elméletének általánosításával a geminálok elméletéhez jutunk. Itt arról van szó, hogy a kémiai kötés két elektronját mát nem egyszerűen egy kétszer betöltött molekulapályával írjuk le, hanem a kötéshez rendelt bázisfüggvények terében a két elektronra a Schrödinger egyenletet egzaktul megoldjuk. A témával Fock 1950-es javaslata ${ }^{3}$ után többen foglalkoztak. Magyarországon Kapuy Ede volt az úttörő, akinek komoly érdemei vannak, hogy a geminálok nemzetközi szinten is nagyobb figyelmet kaptak az 1960-as évektől.

A mi idevágó eredményeink közül az első egy új, kémiai jelentéssel bíró formalizmus kiépítése volt. Ezt úgy lehet legkönnyebben megfogalmazni, hogy a kételektronos kémiai kötést létrehozó, korrelált elektronpárt (és a magányos párokat is) egy kvázi bozon szerü összetett részecskének tekintjük. Mivel a leírása a kémiai kötésen belül egzakt, a geminálokból álló hullámfüggvények hiányosságai közvetlenül a kételektronos kémiai kötés képének, a Lewis szerkezet modelljének a korlátait jelzik.

Ennek a témának a müvelése jelenleg is nagy intenzitással folyik laboratóriumunkban. A téma iránt mélyebben érdeklődő olvasók számára két összefoglaló publikációt tudunk ajánlani ${ }^{4,5}$.

\subsection{Perturbációszámítás}

Laboratóriumunk talán legtöbb figyelmet keltett eredményei a perturbációszámítással állnak kapcsolatban. A címben megadott témához ezek úgy kapcsolódnak, hogy a geminálok közötti kölcsönhatást is sikeresen írtuk le 
perturbációs eszközökkel. A témában az alábbi fontosabb eredmények születtek:

1. Intermolekuláris kölcsönhatások perturbációs leírása (föleg Mayer Istvánnal).

2. Kémiai kötések kölcsönhatásainak perturbációs elmélete.

3. A Rayleigh-Schrödinger perturbációs elmélet általánosítása a nemlineáris Schrödinger egyenlet esetére. Ilyen egyenlet adódik például akkor, ha egy molekulát nem in vacuo, hanem környezetében vizsgálunk, és a mulekula által polarizált környezet visszahat a molekulára.

4. Csillapított perturbációszámítás: szingulárissá váló perturbációs nevezők kiküszöbölése.

5. A partíció problémája a a perturbációszámításban ${ }^{6}$. Nem konvencionális partíciók vizsgálata. A Dyson partíció bevezetése: Korrelált ionizációs potenciálok alkalmazása a Hartree-Fock pályaenergiák helyett az elektronkorreláció perturbatív formuláiban alakilag helyes disszociációs potenciálgörbék számítása céljából egydetermináns alapú ("single reference") elméletekben. A Dyall-partíció kémiai alkalmazásai: kéttest kölcsönhatások bevezetése a nulladrendü operátorban. Konstans nevezőjü (=szingularitás mentes) perturbációs képletek alkalmazása. Az "optimált partíció" fogalmának kidolgozása és alkalmazása. Egy új eljárás, az ún. multikonfigurációs perturbációszámítás (MCPT) kidolgozása. A korrelációs energia Moller-Plesset energiakorrekcióinak kifejezése a Hartree-Fock sürüségmátrix funkcionáljaként a perturbációs nevezők Laplacetranszformáltja segítségével. Végül legújabban: divergens perturbációs sorok felösszegzése az analitikus folytatás módszereinek segítségével.

\section{4. Összefoglaló}

Ebben a beszámolóban szubjektív szempontok alapján soroltuk fel a hazai kvantumkémiai kutatások azon meghatározó személyiségeit, akik a Laboratóriumunkban végzett munkánkra nagy hatással voltak. Címszavakban foglaltuk össze Laboratóriumunk legfontosabb eredményeit. Ezekből a munkákból 1980 és 2018 között 150 nemzetközi és 10 hazai publikáció született, az előbbiek többségükben a szakma vezető folyóirataiban jelentek meg. A publikációkra eddig több, mint 2700 független idézet érkezett.

A szerző köszönettel tartozik az MTA Kémiai Osztályának, hogy a jelen összefoglaló témájában 2018 tavaszán lehetőséget teremtett egy ilyen szemléletű ismertető előadás megtartására. Munkánkat folyamatosan támogatta az OTKA, jelenleg az NKFIH K115744 projektjén keresztül. A potenciálisan anyagtudományi jelentőségü módszerfejlesztések miatt köszönet illeti még a az ELTE 783-3/2018/FEKUTSRAT kiválósági programját is.

\section{Hivatkozások}

1. K. Gavroglu and A. Simoes, Neither Physics nor Chemistry: a History of Quantum Chemistry, The MIT Press, Cambridge, Massachusetts, London, England, 2011. ISBN: 978-0262016186 https://doi.org/10.7551/mitpress/9780262016186.001.0001

2. M. V. Lakshmikatham, D. Lorcy, C. Kordis-Kelley, J.P. Prakka, R. Metzger and M.P. Cava, Adv Materials 1993, 5, 723-726, https://doi.org/10.1002/adma.19930051007

3. F.A. Fock, Dokl. Akad. Nauk USSR 195073735

4. P. R. Surján, An Introduction to the Theory of Geminals, Topics in Current Chemistry, 1999203 63-88 https://doi.org/10.1007/3-540-48972-X_4

5. P. R. Surján, Geminal Approach, Reference Module in Chemistry, Molecular Sciences and Chemical Engineering, Theoretical and Computational Chemistry, Ed. Jan Reedijk, Hiromi Nakai et al., Elsevier, 2016 ISBN: 978-0-12-409547-2 https://doi.org/10.1016/B978-0-12-409547-2.11468-4

6. P.R. Surján and Á. Szabados, APPENDIX TO "STUDIES IN PERTURBATION THEORY": THE PROBLEM OF PARTITIONING, in: Fundamental World of Quantum Chemistry, A Tribute to the Memory of Per-Olov Löwdin, Vol. III., 129-185, eds.: E. J. Brändas and E. S. Kryachko, Kluwer, Dordrecht, 2004, https://doi.org/10.1007/978-94-017-0448-9_8 


\section{Electron localization and the chemical bond}

This review lists the names of a few Hungarian quantum chemists whose work has significant impact on the work of the present author. Then, a couple of research topics are mentioned which have been under study the the author's Laboratory in the last decades, followed by a summary of the most important results.

Hungarian quantum chemistry begins with the significant work by Imre Fényes, Pál Gombás, Péter Szépfalussy and Rezső Gáspár, who were physicists and have results in the field of statistical atomic theory and pseudopotentials. Later, the name of Ferenc Török has to be mentioned. He was an experimetal spectroscopist, a chemist, who has realized the importance of quantum chemistry in the 1960's and started to teach it to chemistry students at the Eötvös Loránt University. János Ladik was working in the quantum theory of polymers and biological systems. Márton Kajtár was an organic chemist, who appreciated quantum chemistry very much and initiated cooperation with quantum chemists both in Hungary and internationally to explain and even to predict chemical phenomena and measurements theoretically. Unfortunately these colleauges are not any more with us.

The key names of the Hungarian quantum chemistry who are still active and whose work has significantly influenced the author's research are: Péter Pulay, Miklós Kertész, Gábor Náray Szabó, István Mayer and Jenő Kürti. Last but not least, I must mention my close friend János Ángyán who left us two years ago and we miss him very much. Of course, quantum chemistry is cultivated currently by many other scientists in Hungary who also have significant work in fields somewhat further from my interest.

The research areas I am (or I was) particularly interested in can be listed as

- CD spectroscopy

- material sciences

- theory of electron correlation

- localization problems in electronic systems

- perturbation theory and its applications to chemical systems.

In CD spectroscopy, I was engaged with the theory of optical rotatory strengths. I was fortunate to cooperate in this subject with Márton Kajtár, István Hermecz and Miklós Hollósi.

In the field of material science, I studied conducting polymers, fullerenes and nanotubes. With Miklós Kertész, we were the first who described trapings of solitons in polyacethylene. With Jenő Kürti, we designed several low-gap polymers theoretically. Understanding and calculating the zero-field splitting of the triplet states of C60 molecule was a fascinating project in my laboratory. Jahn-Teller distortion in fullerenes and in nanotubes was also an interesting study.

A few keywords in the field of electron correlation theory I have worked with my students are: connected moments, geminal-based multi-reference theories, excited states of molecular systems, coupled cluster theory, high-rank Hartree-Fock methods.

An important subject I was very much interested in from the 1980 -s, and I am still interested, is the localization problem and the theoretical model of the chemical bond. Cooperating extensively with Gábor Náray Szabó, István Mayer, János Ángyán and György Ferenczy, we constructed a priori localized molecular orbitals and used them to classify delocalising (through space and through bond) interactions. This theory gave a simple explanation of the origin of torsional barriers.

By generalizing the concept of localized molecular orbitals, we arrived at the theory of two-electron functions, the so called geminals. We constructed an algebraic formalism to deal with geminals by describing the localized chemical bonds as composite quasiparticles consisting of two electrons. The chemical message of this model is important: since the description of geminals within the chemical bond is exact, any failure of this picture is connected to the limitation of the concept of localized chemical bonds.

Main results in perturbation theory: description of inter-molecular and inter-bond interactions, generalization to non-linear Schrödinger equations, damping in perturbation theory, the threory of partitioning in perturbation theory, introduction of optimal partitioning, development of multi-configuration perturbation theory, description of perturbative corrections of electron correlation as a functional of the Hartree-Fock density matrix.

Very recently we study different mathematical tools for the resummation of divergent perturbational series.

Between 1980 and 2018 some 150 international paper was published on the above topics, and 10 more in Hungarian journals. They attracted close to 3000 independent citations. 